\title{
Research on Used Car Evaluation Methods Based on Performance Indicators Weighting Revising
}

\author{
Zhongke Xiang $^{1, a}$, Feifei Xiang ${ }^{1, b}$ \\ 1 Jiangxi University of science and technology, Nanchang, Jiangxi province, China \\ axiangffei@126.com, ’xiangzke@126.com
}

Keywords: Used car evaluation, Performance indicators, Weighting revising.

\begin{abstract}
It is proposed in this paper based on the research of quantifiable indicators used car evaluation system, through to the assets evaluation theory is commonly used in four kinds of evaluation methods on the basis of comprehensive analysis, chose the quantifiable as used car appraisal method of the main theoretical basis, in comprehensive consideration of various factors influencing the used-car prices, on the basis of using the weight of performance indicators will be used car evaluation method is more reasonable design, through the determination of each performance index weights, the integrated use of the weighted coefficient method for the computation of the surplus value of the car can make the used-car evaluation is more quick and convenient, the evaluation process more transparent, to accelerate the process of the construction of the used car market in China. At the same time, also makes the second-hand evaluation has the theoretical basis, reduce the used-car evaluation difference caused by human factors, so that the used car evaluation more formal, more objectively reflect the residual value of second-hand cars.
\end{abstract}

\section{Introduction}

According to data released by the Chinese automobile circulation association, the used-car market trading volume has reached 5.2033 million in 2013, Although compared to the same period last year growth of $8.60 \%$, but the new car volume more than 20 million vehicles. The sales ratio is about 0.26 , and 1.4 in the United States. Therefore, relative to the European and American countries, China's second-hand car market development has a very large space. At present, domestic second-hand car market "'" scattered, disorder and poor lack of integrity of industry" such as performance, is still the key problem which restricts the healthy development of second-hand car market, car condition, price is not transparent and other problems to be solved. In this paper, based on researching the quantitative indicators of second-hand car evaluation is a kind of speaking with actual data, increase transparency and consumer attention is taken into account a used-car evaluation method.

\section{Used car evaluation method based on quantifiable indicators}

Used car evaluation method based on quantifiable indicators, through to the assets evaluation theory is commonly used in four kinds of evaluation methods on the basis of comprehensive analysis, the quantifiable as the main theoretical basis of used car appraisal method, On the basis of considering various factors influencing the used-car prices, The index weight used in car is more reasonable, Through the determination of each performance index weights, The integrated use of the weighted coefficient method for the computation of the surplus value of the car can make the used-car evaluation is more quick and convenient, Accelerate the process of the construction of the used car market in China. 


\section{The selection of performance indicators and the determination of coefficient 3.1 The selection of performance indicators}

The First, engine: The effective power of an engine, Brand (resale value), The diesels run idle , oil consumption, ignition timing, fuel pressure, Oil pressure, compression pressure of each cylinder, air leaking to crankcase, The cooling system to keep stress.

The second, Chassis: accelerating time for $0-100 \mathrm{~km} / \mathrm{h}$, Best fuel consumption, Braking distance (The speed is $100 \mathrm{~km} / \mathrm{h}$ ), Maximum speed, Clutch (skid, separation is not clear, started shaking), Transmission (whether or not the spill, sound, jump to block, block), Braking time (braking efficiency), the abrasion of absorber, Coasting ability at $20 \mathrm{~km} / \mathrm{h}, \mathrm{CAR}$ pulls to one side (during brake ), directive wheel sliding, Check drive train traveling Angle.

Third, electrical equipment: check whether the air bag is safe, check whether the electronic door locks and anti-theft device is intact, The pressure and sealing of air conditioning system, the stereo and sound performance, the indication error of Speedometer, The voltage of electric generator.

Fourth, Car body: check whether the front bumper is distorted, check whether the anti-collision beam is distorted, whether the vehicle outline is distorted, the abrasion of tire, check whether the paint is even, check whether the front and back windshield glasses is change, The indoor attrition level, Vehicle travel, hub deformation and wandering.

\subsection{Questionnaire design and selection of objects}

This questionnaire is mainly design for four kinds of people: maintenance technicians, consumers, the expert and appraiser.

At the beginning of the first, we choose the auto index to investigate all aspects, For each performance index and set up four options: very important, more important, as important, is not important. Statistical analyses were conducted according to the questionnaire results, Then several typical indicators were selected and graded them, Important assignment in 4 points, the more important assignment in 3 points, general important assignment in 2 points, not important assignment in 1 points. So you can according to each performance index score see the importance of the performance index, which is more reasonable to determine the coefficient of performance indicators.

Through formula (1)to calculate the weight coefficient of indicators:

$$
\lambda=\frac{\text { single item evaluation index cent value }}{\text { evaluation total cent value }}
$$

After the final selection, Chose this 39 parameters for the main performance, and calculated the coefficient of each performance indicators (as shown in table 1), Then calculate depreciation of each performance, finally, the value of the car was determined. Statistical analysis as follows: 
Table 1 Each performance index score and their weights

\begin{tabular}{|c|c|c|c|c|c|c|c|}
\hline Item & Performance Index & Score & $\begin{array}{l}\text { weight } \\
\text { coefficient } \\
\lambda \mathrm{i}\end{array}$ & Item & Performance Index & Score & $\begin{array}{l}\text { weight } \\
\text { coefficient } \\
\text { t } \lambda \mathrm{i}\end{array}$ \\
\hline \multirow{9}{*}{$\begin{array}{l}\text { engine } \\
7070\end{array}$} & $\begin{array}{l}\text { The effective power of } \\
\text { an engine }\end{array}$ & 955 & 0.03194 & \multirow{12}{*}{$\begin{array}{l}\text { Chassis } \\
9250\end{array}$} & $\begin{array}{l}\text { accelerating time of } 0-100 \\
\mathrm{~km} / \mathrm{h}\end{array}$ & 615 & 0.020569 \\
\hline & Engine idle speed & 765 & 0.025585 & & Best fuel consumption & 875 & 0.029264 \\
\hline & oil consumption & 865 & 0.02893 & & $\begin{array}{l}\text { Braking distance (The } \\
\text { speed is } 100 \mathrm{~km} / \mathrm{h} \text { ) }\end{array}$ & 925 & 0.030936 \\
\hline & ignition timing & 790 & 0.026421 & & Maximum speed & 630 & 0.02107 \\
\hline & fuel pressure & 730 & 0.024415 & & $\begin{array}{l}\text { Clutch (skid, separation is } \\
\text { not clear, started shaking) }\end{array}$ & 850 & 0.028428 \\
\hline & Oil pressure & 670 & 0.022408 & & $\begin{array}{l}\text { Transmission (whether or } \\
\text { not the spill, sound, jump to } \\
\text { block, block) }\end{array}$ & 895 & 0.029933 \\
\hline & $\begin{array}{l}\text { compression pressure of } \\
\text { each cylinder }\end{array}$ & 760 & 0.025418 & & $\begin{array}{l}\text { Braking time (braking } \\
\text { efficiency) }\end{array}$ & 880 & 0.029431 \\
\hline & air leaking to crankcase & 715 & 0.023913 & & the abrasion of absorb & 805 & 0.026923 \\
\hline & $\begin{array}{l}\text { The cooling system to } \\
\text { keep stress }\end{array}$ & 820 & 0.027425 & & Coasting ability at $20 \mathrm{~km} / \mathrm{h}$ & 600 & 0.020067 \\
\hline \multirow{8}{*}{$\begin{array}{l}\text { Car } \\
\text { body } \\
5995\end{array}$} & $\begin{array}{l}\text { whether the front } \\
\text { bumper is distorted }\end{array}$ & 765 & 0.025585 & & $\begin{array}{l}\text { CAR pulls to one side } \\
\text { (during brake ) }\end{array}$ & 790 & 0.026421 \\
\hline & $\begin{array}{l}\text { Whether the } \\
\text { anti-collision beam is } \\
\text { distorted }\end{array}$ & 765 & 0.025585 & & directive wheel sliding & 730 & 0.024415 \\
\hline & $\begin{array}{l}\text { whether the vehicle } \\
\text { outline is distorted }\end{array}$ & 825 & 0.027592 & & $\begin{array}{l}\text { Check drive train traveling } \\
\text { Angle }\end{array}$ & 655 & 0.021906 \\
\hline & the abrasion of tire & 760 & 0.025418 & \multirow{7}{*}{$\begin{array}{l}\text { electrical } \\
\text { equipment } \\
5250\end{array}$} & whether the air bag is safe & 895 & 0.029933 \\
\hline & whether the paint is even & 620 & 0.020736 & & $\begin{array}{l}\text { whether the electronic door } \\
\text { locks and anti-theft device } \\
\text { is intact }\end{array}$ & 880 & 0.029431 \\
\hline & $\begin{array}{l}\text { whether the front and } \\
\text { back windshield glasses } \\
\text { is change }\end{array}$ & 715 & 0.023913 & & $\begin{array}{l}\text { The pressure of the air } \\
\text { conditioning system }\end{array}$ & 670 & 0.022408 \\
\hline & The indoor attrition level & 605 & 0.020234 & & $\begin{array}{l}\text { The sealing of the air } \\
\text { conditioning system }\end{array}$ & 690 & 0.023077 \\
\hline & $\begin{array}{l}\text { Wheel deformation and } \\
\text { wandering. }\end{array}$ & 940 & 0.031438 & & $\begin{array}{l}\text { The stereo and sound } \\
\text { performance }\end{array}$ & 610 & 0.020401 \\
\hline \multirow{3}{*}{$\begin{array}{l}\text { Others } \\
2335\end{array}$} & Brand (resale value) & 805 & 0.026923 & & $\begin{array}{l}\text { The indication error of } \\
\text { Speedometer, }\end{array}$ & 685 & 0.02291 \\
\hline & Vehicle travel & 810 & 0.02709 & & $\begin{array}{l}\text { The voltage of electric } \\
\text { generator. }\end{array}$ & 820 & 0.027425 \\
\hline & engine noise & 720 & 0.02408 & & & & \\
\hline
\end{tabular}

\section{A surplus value calculation method of used car Based on the weighted performance indicators}

\subsection{Surplus value calculation method of measurable performance indicators}

A total of 20 Measurable car depreciation rate indicators, They are effective power of an engine (engine power when wide Open throttle), The diesels run idle(engine power for $20 \mathrm{kw}$ ), oil consumption The oil consumption of $100 \mathrm{~km}$ (The ratio of oil consumption and theory of $100 \mathrm{~km}$ ) ,ignition timing (The engine rotational speed for $800 \mathrm{r} / \mathrm{min}$ ), fuel pressure(The engine rotational speed for $800 \mathrm{r} / \mathrm{min}$ ), Oil pressure(The engine rotational speed at 800 $\mathrm{r} / \mathrm{min}$ ), compression pressure of each cylinder(The engine rotational speed for 800 $\mathrm{r} / \mathrm{min}$ ), compression pressure of each cylinder, air leaking to crankcase(The engine rotational speed for $800 \mathrm{r} / \mathrm{min}$ ), accelerating time for $0-100 \mathrm{~km} / \mathrm{h}$, Best fuel consumption in constant speed (The speed of $80 \mathrm{~km} / \mathrm{h}$ ), Braking distance (The speed of $100 \mathrm{~km} / \mathrm{h}$ ), Maximum speed( $\operatorname{maximum}$ power) ,Braking time (braking efficiency) the speed of $80 \mathrm{~km} / \mathrm{h}$, Coasting ability at $20 \mathrm{~km} / \mathrm{h}$, CAR pulls to one side (during brake ) at $30 \mathrm{~km} / \mathrm{h}$, directive wheel sliding at $5 \mathrm{~km} / \mathrm{h}$, The pressure of air 
conditioning system (High-pressure pipe), The voltage of electric generator (The engine rotational speed at $800 \mathrm{r} / \mathrm{min}$ ), the abrasion of tire, Engine noise (engine idle speed at $800 \mathrm{r} / \mathrm{min}$ ). Through the formula (2) to calculate depreciation, $\alpha \mathrm{i}$ is allowance for depreciation

$$
\alpha_{i}=\left|\frac{\text { The index parameters of assessment }- \text { The index parameters of new car }}{\text { The index parameters of new car }}\right| \times 100 \%
$$

\subsection{Surplus value calculation method of immeasurable performance indicators}

There is a part of index cannot be measured, Or measurement standard is not clear, Such as safety clutch skid. Can be considered according to the actual index is divided into several levels, Each level corresponds to an allowance for depreciation, Its weight coefficient is obtained by investigation.

(1) air tightness of Cooling system: Best 1.0, Better 0.8, Generally 0.6, Worse 0.5, bad 0.4

(2)Clutch (skid, separation is not clear, started shaking) : Best 1.0, Better 0.8, Generally 0.6, Worse 0.5 , bad 0.4

(3) Transmission (whether or not the spill, sound, jump to block, block) : Best 1.0, Better 0.8, Generally 0.6, Worse 0.5 ,bad 0.4

(4) drive train traveling Angle : Best 1.0, Better 0.8, Generally 0.6, Worse 0.5, bad 0.4

(5) the abrasion of absorber : Best 1.0, Better 0.8, Generally 0.6, Worse 0.5, bad 0.4

(6) the abrasion of absorber : Best 1.0, Better 0.8, Generally 0.6, Worse 0.5, bad 0.4

(7) whether the electronic door locks and anti-theft device is intac : Best 1.0, Better 0.8, Generally 0.6 , Worse 0.5 , bad 0.4

(8) The sealing of air conditioning system: Best 1.0 , Better 0.8 , Generally 0.6 , Worse 0.5 , bad 0.4

(9) the stereo and sound performance: Best 1.0, Better 0.8, Generally 0.6, Worse 0.5, bad 0.4

(10) the indication error of Speedometer: Best 1.0, Better 0.8, Generally 0.6, Worse 0.5,bad 0.4

(11) whether the front bumper is distorted: Best 1.0, Better 0.8, Generally 0.6, Worse 0.5,bad 0.4

(12) whether the anti-collision beam is distorted: Best 1.0, Better 0.8, Generally 0.6, Worse 0.5 , bad 0.4

(13) whether the vehicle outline is distorted: Best 1.0, Better 0.8, Generally 0.6, Worse 0.5,bad 0.4

(14) whether the paint is even: Best 1.0, Better 0.8, Generally 0.6, Worse 0.5, bad 0.4

(15) whether the front and back windshield glasses is change: There is no 1.0 , There are 0.5

(16) The indoor attrition level: Best 1.0, Better 0.8, Generally 0.6, Worse 0.5,bad 0.4

(17) hub deformation and wandering 1: Best 1.0, Better 0.8, Generally 0.6, Worse 0.5, bad 0.4

(18) Brand (resale value): Best 1.0, Better 0.8, Generally 0.6, Worse 0.5,bad 0.4

(19) Vehicle travel: years of use $<1$ year, Vehicle travel $<20000$ Depreciation is 0.9 ; years of use $<3$ year, Vehicle travel $<60000$ Depreciation is 0.8 ; years of use $<5$ year, Vehicle travel $<100000$ Depreciation is 0.6; Vehicle travel $<160000$ Depreciation is 0.4

Through the study of the depreciation of each performance index, calculate the residual value of the car, calculation formula is:

$$
\text { The residual value of the } \operatorname{car} P=\sum_{i=1}^{i=20} \lambda_{i}\left(1-\alpha_{\mathrm{i}}\right) \times P_{0}+\sum_{j=1}^{j=19} \lambda_{j}^{\prime} \times \beta_{j} \times P_{0}
$$

$\alpha_{i^{--}}$Measurable performance indicators depreciation rate;

$P_{0^{--}}$The original value of the car;

$\lambda_{i^{--}-\text {weight coefficient of measurable performance indicators }}$

$\beta_{j^{---}}$Residual value rate of unmeasured performance

$\lambda_{j}$---index weights of unmeasured performance 


\section{Conclusions}

(1)By a new design for used car evaluation methods, To quantify each performance indicators, Make the assessment more reasonable and more objective reflection of the car of the surplus value.

(2) In this paper, through the questionnaire survey method, We can understand the consumer awareness of various performance indicators, Through the maintenance technicians, consumers, investigate the expert and appraiser, We can choose the more reasonable performance indicators, the performance of the selected indicators can more effectively reflect the residual value of car.

(3) Statistical analyses were conducted according to the questionnaire results, Chose the correct performance, and calculated the coefficient of each performance indicators, So that more scientifically reflect the importance of each performance index, avoid personal subjective factors affect vehicle performance index weights .Then calculate depreciation of each performance, finally, the value of the car was determined, And close to the actual evaluation results.

\section{Acknowledgements}

This work was financially supported by the Jiangxi University of Technology Natural Science Foundation (ZR12YB03), Collaborative Innovation Project Automotive Disciplines of Jiangxi University of Technology (xtcx201302) and Science and Technology support Project of Science and Technology Office of Jiangxi Province (2016BBE50053).

\section{References}

[1] Wu Qiu-Li, Wang Tong, Zhang Ya-Ping etc. Abroad used car evaluation system for the enlightenment of our country [J]. The automotive industry research,2013, (4) : 11-15.

[2] Ding Hai-Bo, Niu Li. Used car performance comprehensive evaluation research Based on improved AHP-Fuzzy[J]. Mechanical and electrical engineering,2013,42 (12) : 79-82.

[3] Feng Xiu-Rong, Wang Bing. Factor analysis of the resale value [J]. Business research,2008, (2): 102-104.

[4] Lu Zhi-Xiong. Used car appraisal of practical manual [M] . NanJing: JiangSu science and technology press, 2007.

[5] Zhou You. evaluation method research Apply to the value of a used car [J]. HeiLongJiang traffic science and technology,2013, (11) : 172-174.

[6] Gao-Bo,Yin Peng-Ran, Liu-Jun. vehicle cars into new rate determination method Based on the comprehensive evaluation $[\mathrm{J}]$. Journal of HeBei agricultural university,2002,25 (5) : 286-288. 